Влияние рН на процесс выделения белковой фракции из растворов травяного клеточного сока

\author{
A.В. Шуваев \\ Сибирский государственный университет путей сообщения (2. Новосибирск)
}

Резюме. Одним из наиболее перспективных способов обезвоживания зелёной массы растений в процессе получения сухих кормов длительного пользования для сельскохозяйственных животных является механическое прессование. Однако получаемый в качестве побочного продукта травяной клеточный сок содержит в своем составе различные питательные вещества, основу которых составляет протеин. В качестве продукта питания использовать клеточный сок не представляется возможным из-за высокого содержания воды и быстро происходящих в нём процессов брожения. Возникает задача поиска наиболее эффективной методики экспрессной переработки травяного сока с целью выделения из него протеинового концентрата. В этом плане несомненный интерес представляют химические способы, основанные на эффекте высаливания белковой фракции под действием электролитных добавок.

В данной работе исследуется характер влияния изменения кислотности среды на процесс выделения белковой фракции из растворов травяного клеточного сока. Осуществлено титрование травяного клеточного сока водными растворами $\mathrm{HCl}$ и $\mathrm{NaOH}$. В щелочных средах не наблюдается коагуляции белковой фракции. В кислых средах при различных значениях $\mathrm{pH}$ выделены образцы протеиновой пасты. Высушиванием образцов получены сухие протеиновые концентраты. Сравнительный анализ процентного содержания атомов $\mathrm{H}, \mathrm{C}, \mathrm{N}$ в различных пробах протеинового концентрата обнаружил тенденцию к их небольшому увеличению при уменьшении значения $\mathrm{pH}$ растворов, из которых они были получены. В образцах протеинового концентрата, выделенных из растворов травяного сока добавлением $\mathrm{HCl}$, по сравнению с образцом, полученным термическим способом, нет существенного различия в суммарном содержании четырёх компонентов: влаги, протеина, жира и клетчатки, меняется лишь пропорция между ними - в последнем выше содержание влаги и жира, и ниже - протеина и клетчатки.

Ключевые слова: травяной клеточный сок, коагуляции белковой фракции, термокоагуляция растительного белка, протеиновый концентрат, сухие зелёные корма.

UDC 636.085.51

\title{
pH influence on isolation of a protein fraction from herbal cell juice
}

\author{
Alexander V Shuvaev \\ Siberian State Transport University (Novosibirsk, Russia)
}

\begin{abstract}
One of the most promising ways to dehydrate the green mass of plants in the process of obtaining dry durable feed for farm animals is mechanical pressing. However, the herbal cell juice been obtaining as a by-product contains various nutrients, the basis of which is protein. It is not possible to use cell juice as a food product because of the high water content and quick occurs fermentation processes in it. The problem arises of finding the most effective methods for the express processing of herbal juice in order to isolate protein concentrate from it. The chemical methods based on the salting out of the protein fraction under the action of electrolyte additives are of undoubted interest in this regard.

The nature of changes effect's in the acidity of the medium on the process of isolating the protein fraction from solutions of herbal cell juice is studying in this paper. The herbal cell juice was titrated with aqueous solutions of $\mathrm{HCl}$ and $\mathrm{NaOH}$. In alkaline media is not observed coagulation of the protein fraction. In acidic media, samples of protein paste have been isolated at different $\mathrm{pH}$ values. Dry protein concentrates
\end{abstract}


were obtained by drying the samples. Comparative analyses of atoms $\mathrm{H}, \mathrm{C}, \mathrm{N}$ percentage in different protein concentrate samples revealed a tendency to them increase slightly with decreasing $\mathrm{pH}$ value of the solutions from which they were obtained. In samples of protein concentrate isolated from solutions of herbal juice by adding $\mathrm{HCl}$, compared with a sample obtained thermally, there is no significant difference in the total content of the four components: moisture, protein, fat and fiber, only the proportion between them changes - in the latter, the moisture and fat content is higher, and lower - protein and fiber.

Keywords: herbal cell juice, coagulation of the protein fraction, thermo coagulation of vegetable protein, proteic concentrate, dry green feed.

\section{Введение.}

Технология получения и заготовки сухих зелёных кормов из растений во многом определяется климатическими условиями региона страны. Для Западной Сибири период второй половины лета-начала осени часто характеризуется неустойчивой дождливой погодой при невысокой солнечной активности. Всё это значительно затрудняет применение в крупных масштабах естественной сушки. Поэтому на первый план выдвигается поиск и развитие наиболее высокоэффективных технологий производства сухих зелёных кормов путём искусственного обезвоживания. В настоящее время существуют два принципиально важных направления: высокотемпературная сушка (Умбетов Е.С. и др., 2016; Киреева В.В., 2004; Попов В.В., 2014) и отжим зелёной массы прессованием (Яковлев Д.А., 2011; Цугленок Н.В. и др., 2012). Оба эти способа обладают как достоинствами, так и недостатками. Недостатки первого связаны с высокими энергозатратами. Второй не требует больших расходов энергии, и это является его преимуществом (Анискин В.И. и Негримовский М.Г., 2005; Ревякин Е.Л., 2013; Полунин А.А. и Абдулкеримов С.А., 2014). При механическом прессовании образуется травяной клеточный сок, в составе которого содержатся многие биологически ценные вещества, такие как протеин, каротин, жир, витамины, микроэлементы (Новиков Ю.Ф. и др., 1985). Использование его в качестве продукта питания осложнено из-за процессов брожения, особенно быстро развивающихся в летний период. В связи с этим актуальной проблемой является поиск высокоэффективного способа переработки травяного сока, позволяющего получать сухие продукты в виде протеиновой пасты (Кощаев А.И. и др., 2004; Петенко А.И. и Кощаев А.И., 2005), а также протеинового концентрата с сохранением в них биологической ценности питательных веществ. Обычно применяемые на практике термические способы выделения белка из растительного сока имеют ряд недостатков: во-первых, энергоёмки в затратах (Прищеп Л.Г. и Бойко А.Я., 1974) и, вовторых, питательные качества продукта ухудшаются из-за термического влияния на состояние органических веществ - белков, витаминов, ферментов (Терпиловский К.Ф. и Примаков Н.С., 1975; Шевцов А.А. и др., 2013).

Ранее нами (Шуваев А.В., 2018; Шуваев А.В., 2019; Гаврилов Д.А. и Шуваев А.В., 2020) был успешно применен электролитный способ (Хисматуллина 3.Н., 2013; Кудряшова Н.С., 2018) выделения белковой фракции из раствора травяного сока. Было обнаружено (Шуваев А.В., 2018; Гаврилов Д.А. и Шуваев А.В., 2020), что ряд электролитов: $\mathrm{Al}_{2}\left(\mathrm{SO}_{4}\right)_{3}, \mathrm{AlCl}_{3}, \mathrm{CuSO}_{4}, \mathrm{FeSO}_{4}, \mathrm{CaCl}_{2}$ проявляют высаливающее действие по отношению к белковой фракции. Определены количества выделенной и высушенной протеиновой пасты из растворов травяного сока как под влиянием добавляемых электролитов, так и путём термической обработки. Полученные образцы анализировались на процентное содержание атомов углерода, водорода, азота и атомов металлов - алюминия, меди, железа, кальция (Шуваев А.В., 2019). Результаты показали: в образцах, полученных электролитным способом, содержание атомов металлов несколько превышает их фоновое содержание в натуральном продукте. Требованию санитарным нормативам, регламентирующих безопасное содержание атомов металлов-микроэлементов в кормовых продуктах (Временный МДУ.., 1989; Калашников А.П. и др., 2003), оказалось, что соответствуют только образцы, полученные с использованием сульфата меди (II) и хлорида кальция.

Представляло интерес изучить влияние изменения кислотности среды на процесс выделения белковой фракции из растворов травяного клеточного сока. 


\section{Цель исследования.}

Получить образцы протеинового концентрата из растворов травяного клеточного сока путём изменения кислотности среды и определить их химический состав на основе физикохимических методов исследования.

\section{Материалы и методы исследования.}

Объект исследования. Протеиновый концентрат, выделяемый из растворов травяного клеточного сока.

Схема эксперимента. Травяной клеточный сок был получен в проблемной лаборатории НГАУ путём механического прессования свежескошенной отавы трав, имеющей следующий состав: люцерна, эспарцет, костер. Травяной сок охлаждали в кристаллизаторе в холодильной камере до температуры $+2 \ldots+3{ }^{\circ} \mathrm{C}$, затем переливали в термос и помещали в холодильник. В дальнейшем из термоса отбирали небольшие порции, необходимые непосредственно для анализа. По визуальным наблюдениям в описанных условиях хранения травяной сок не претерпевал каких-либо заметных изменений в течение недели.

Измерение величин рН осуществляли на стандартном рН-метре 323 при температуре $+18 \pm 1{ }^{\circ} \mathrm{C}$. Используемый в исследованиях рН-метр 323 находился в нормальном рабочем состоянии, позволяющим производить точные измерения величин $\mathrm{pH}$ с абсолютной ошибкой, не превышающей $\pm 0,01$ ед. $\mathrm{pH}$. Калибровку шкалы прибора производили по бифталатному, фосфатному и боратному буферным растворам (Бейтс Р., 1972). Были приготовлены стандартные растворы: 0,1 и 1 н $\mathrm{HCl}$; 0,1 и 1 н $\mathrm{NaOH}$. Затем осуществили титрование травяного сока. К 20 мл травяного сока при перемешивании добавляли определённые количества $\mathrm{HCl}$ или $\mathrm{NaOH}$ и определяли значения рН. "Чистый" раствор травяного клеточного сока имеет значение $\mathrm{pH}=5,70$. Все дальнейшие исследования травяного сока проводили с объёмом, равным 10 мл.

Измерение массы высушенных проб протеиновой пасты - протеинового концентрата осуществляли на аналитических весах ВЛР-20. Анализ образцов протеинового концентрата на содержание влаги, протеина, жира и клетчатки осуществляли по методу регистрации спектров отражения анализируемых проб в ближней инфракрасной области с помощью ИК-анализатора ФТ-12. Предварительно осуществлялась градуировка ИК-анализатора по каждому показателю. Для этого использовались около 40 градуировочных образцов, для которых значения массовых долей анализируемого показателя в наборе для градуировки равномерно распределялись по всему диапазону измерений. Значение коэффициента корреляции градуировочной модели составляло 0,95.

Оборудование и технические средства. Исследования проводили в лаборатории микроанализа НИОХ СО РАН и в секторе биохимии проблемной лаборатории НГАУ, использовали: мерную лабораторную посуду; аналитические весы ВЛР-20 («Госметр», г. Санкт-Петербург); рНметр 323; центрифугу CM-12-06; сушильный шкаф SNOL; автоматический анализатор CHN-240G («Perkin Elmer», США); анализатор инфракрасный инфралюм фт-12.

Статистическая обработка. Все измерения с пробами травяного клеточного сока, а также с выделяемыми из них образцами протеинового концентрата, проводили дважды независимо, полученные результаты усредняли. Во всех случаях различие в результатах не превышало 2-3 \%.

\section{Результаты исследований.}

На рисунке 1 приведены результаты титрования травяного клеточного сока.

Характерно, что цвет раствора в зависимости от $\mathrm{pH}$ меняет свою окраску: в кислых средах от ярко-зелёного до жёлто-зелёного, в щелочных - до тёмно-зелёного. На основе полученных результатов были построены графические зависимости величин $\Delta \mathrm{pH} / \Delta C$ от $C_{\mathrm{NaOH}}\left(C_{\mathrm{HCl}}\right)$. Из рисунка 2 можно видеть, что как в кислой, так и щелочной областях функция $\Delta \mathrm{pH} / \Delta C$ имеет отчётливо выраженные экстремумы. 

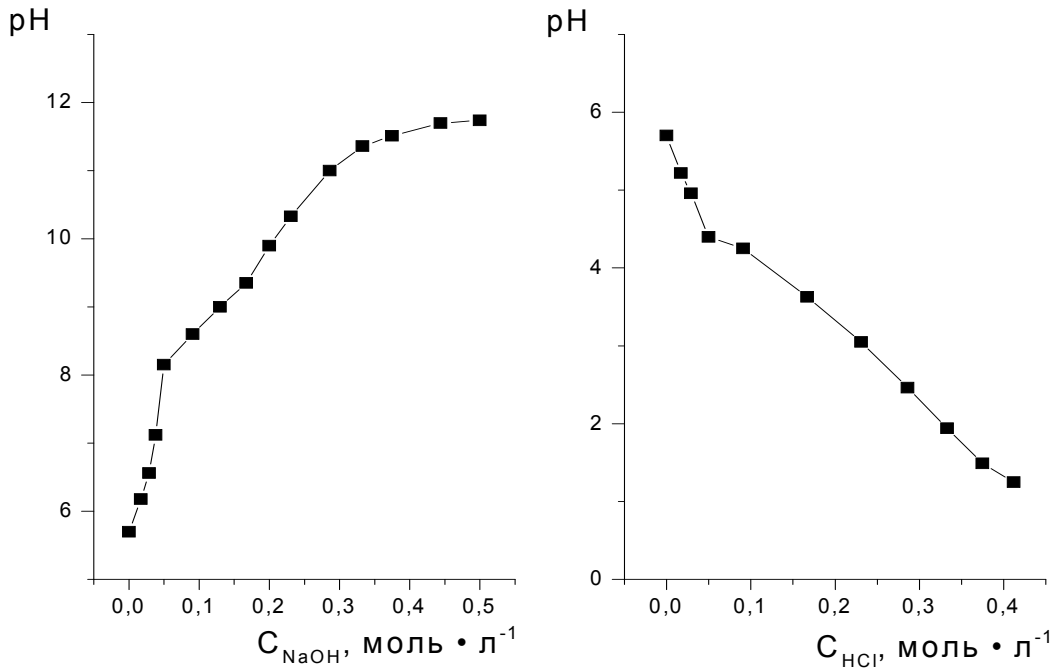

Рис. 1 - Зависимость рН травяного клеточного сока от количества добавляемой кислоты или щёлочи

Figure 1 - The dependence of the $\mathrm{pH}$ of herbal cell juice on the amount of adding acid or alkali
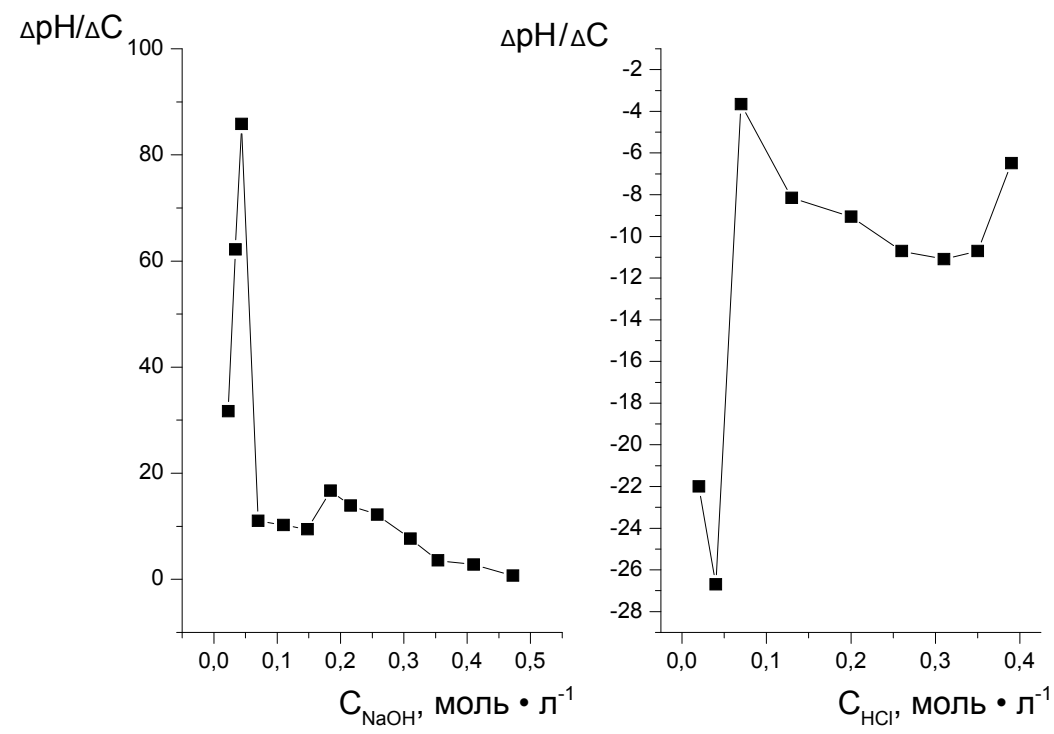

Рис. 2 - Зависимость функции $\Delta \mathrm{pH} / \Delta C$ от концентрации $\mathrm{HCl}(\mathrm{NaOH})$

Figure 2 - Dependence of the function $\Delta \mathrm{pH} / \Delta C$ on the concentration of $\mathrm{HCl}(\mathrm{NaOH})$

Это наглядно подтверждает амфотерный характер свойств протеина травяного сока. В щелочной среде максимум функции достигается при $C_{\mathrm{NaOH}} \sim 0,04$ моль/л $(\mathrm{pH} 7,4)$. В кислой среде имеет место минимум функции при $C_{\mathrm{HCl}} \sim 0,05$ моль/л $(\mathrm{pH} \sim 4,4)$. В областях $C_{\mathrm{NaOH}} \geq 0,1$ моль/л $(\mathrm{pH} \geq 8,7)$ и $C_{\mathrm{HCl}} \geq 0,12$ моль/л $(\mathrm{pH} \leq 3,9)$ практически завершается титрование протеина травяного сока. Для 
дальнейших исследований нами были выбраны растворы с фиксированными значениями $\mathrm{pH}=1,25$; $2 ; 3 ; 4 ; 8 ; 10$. Этими растворами заполняли пробирки (примерно наполовину) и устанавливали их в гнезда центрифуги. Центрифугировали в течение 10 мин при скорости вращения 1500 об./мин. Затем декантацией отделяли осадок от раствора. Цвет раствора над осадком был следующим: раствор с $\mathrm{pH}=1,25$ - коричневый, $\mathrm{pH}=2$ - светло-коричневый, $\mathrm{pH}=3$ и 4 - жёлтый. В пробах с $\mathrm{pH}=8$ и 10 после центрифугирования нет чёткого расслоения между осадком и раствором. Незначительная часть тёмно-зелёного раствора сверху при попытке его отделить легко взбалтывается с осадком. Такие же результаты получаются и при центрифугировании "чистого" травяного сока (без добавок электролитов). Таким образом, в щелочных средах коагуляции белковой фракции не наблюдается. Дальнейшие измерения мы ограничили областью кислых растворов. С этой целью в несколько стаканчиков наливали одинаковый объём травяного сока - 10 мл и, согласно кривой титрования, добавляли определённые количества $\mathrm{HCl}$. После перемешивания растворов их центрифугировали и декантировали осадки от растворов. Осадки промывали дистиллированной водой для очистки от возможного присутствия ионов $\mathrm{H}^{+}$и $\mathrm{Cl}^{-}$с последующим центрифугированием и декантацией. Процедуру повторяли несколько раз до нейтральной реакции промывных вод. В каждом случае число повторов было разным. Для растворов с первоначальным значением $\mathrm{pH}=1$ и 2 - от 8 до 10 раз; $\mathrm{pH}=3$ и 4 - от 5 до 6 раз; $\mathrm{pH}=5-8$ - от 2 до 3 раз.

Полученные влажные осадки количественно переносили в выпарные фарфоровые чашки и помещали в сушильный шкаф. Сушку осуществляли при температуре, не превышающей $+60{ }^{\circ} \mathrm{C}$, в течение нескольких суток до постоянного веса (на ночь сушильный шкаф отключался). Все опыты с конкретным значением pН повторяли, результаты усредняли. Аналогичную процедуру осуществляли с белковой фракцией, выделенной термическим способом. Результаты приведены в таблице 1.

Таблица 1. Высушивание образцов протеиновой пасты Table 1. Drying of protein paste samples

\begin{tabular}{|c|c|c|c|c|c|c|}
\hline \multirow{2}{*}{$\begin{array}{c}\text { Значение } \mathrm{pH} / \\
\text { PH value }\end{array}$} & \multicolumn{6}{|c|}{ Масса выделенной протеиновой пасты, г/ The mass of the selected protein paste, $g$} \\
\hline & $\begin{array}{c}1 \text { сутки/ } \\
1 \text { day }\end{array}$ & $\begin{array}{c}2 \text { суток/ } \\
2 \text { days }\end{array}$ & $\begin{array}{c}3 \text { суток/ } \\
3 \text { days }\end{array}$ & $\begin{array}{c}4 \text { суток/ } \\
4 \text { days }\end{array}$ & $\begin{array}{c}5 \text { суток/ } \\
5 \text { days }\end{array}$ & $\begin{array}{c}\text { среднее/ } \\
\text { average }\end{array}$ \\
\hline \multirow{2}{*}{1,25} & 0,6781 & 0,6833 & 0,6825 & 0,6861 & 0,6869 & \multirow{2}{*}{0,719} \\
\hline & 0,7435 & 0,7476 & 0,7462 & 0,7501 & 0,7506 & \\
\hline \multirow[b]{2}{*}{2} & 1,0969 & 1,0941 & 1,0846 & 1,0850 & 1,0856 & \multirow{2}{*}{0,910} \\
\hline & 0,7281 & 0,7331 & 0,7294 & 0,7334 & 0,7347 & \\
\hline \multirow[b]{2}{*}{3} & 0,7678 & 0,7700 & 0,7672 & 0,7704 & 0,7712 & \multirow[b]{2}{*}{0,835} \\
\hline & 0,9020 & 0,8989 & 0,8950 & 0,8985 & 0,8994 & \\
\hline \multirow{2}{*}{4} & 1,2061 & 1,1983 & 1,1921 & 1,1914 & 1,1905 & \multirow{2}{*}{1,070} \\
\hline & 0,9538 & 0,9509 & 0,9470 & 0,9483 & 0,9494 & \\
\hline $\begin{array}{l}\text { Термический } \\
\text { способ/ }\end{array}$ & 1,0919 & 1,0899 & 1,0836 & 1,0796 & 1,0830 & \\
\hline Thermal method & 0,9391 & 0,9234 & 0,9239 & 0,9185 & 0,9208 & 1,002 \\
\hline
\end{tabular}

Образцы протеиновых концентратов анализировали на процентное содержание атомов углерода, водорода и азота в лаборатории микроанализа НИОХ СО РАН. Результаты приведены в таблице 2.

Образцы протеиновых концентратов анализировали на процентное содержание ряда компонентов - влаги, протеина, жира и клетчатки. Исследования осуществляли в секторе биохимии проблемной лаборатории НГАУ. Результаты приведены в таблице 3. 
Таблица 2. Процентное содержание атомов в пробах протеинового концентрата Table 2. The percentage of atoms in samples of protein concentrate

\begin{tabular}{|c|c|c|c|}
\hline $\begin{array}{c}\text { 3начение pH */ } \\
\text { pH value * }\end{array}$ & \% C & \% H & \% N \\
\hline 1,25 & 51,07 & 6,77 & 6,81 \\
Среднеe/ Average & 50,89 & 6,79 & 6,29 \\
\hline 2 & 50,98 & 6,78 & 6,55 \\
\hline Среднеe/ Average & 49,97 & 6,75 & 5,85 \\
\hline 3 & 49,33 & 6,57 & 5,92 \\
\hline Среднеe/ Average & 49,65 & 6,66 & 5,88 \\
\hline 4 & 47,95 & 6,54 & 5,49 \\
& 49,01 & 6,65 & 5,44 \\
\hline Среднее/ Average & 48,48 & 6,58 & 5,46 \\
\hline Tермический способ/ & 45,20 & 6,33 & 4,79 \\
Thermal method & 45,25 & 6,15 & 4,66 \\
\hline Среднее/ Average & 46,22 & 6,24 & 4,72 \\
\hline
\end{tabular}

Примечание: * - приведены результаты анализа проб протеинового концентрата, полученного из растворов травяного сока при соответствующих значениях $\mathrm{pH}$

Note: * - results of analysis of protein concentrate samples obtained from herbal juice solutions at corresponding $\mathrm{pH}$ values are given

Таблица 3. Химический состав воздушно-сухих проб протеинового концентрата, высушенные при $+60^{\circ} \mathrm{C}$

Table 3. Chemical composition of air-dried protein concentrate samples, dried at $+60{ }^{\circ} \mathrm{C}$

\begin{tabular}{|c|c|c|c|c|c|c|}
\hline \multirow{2}{*}{$\begin{array}{c}\text { Номер } \\
\text { пробы/ } \\
\text { Sample } \\
\text { No }\end{array}$} & \multirow[b]{2}{*}{$\begin{array}{c}\text { Значение } \mathrm{pH} / \\
\text { pH value }\end{array}$} & \multicolumn{5}{|c|}{ Процентное содержание/Percentage } \\
\hline & & $\begin{array}{l}\text { влага/ } \\
\text { moisture }\end{array}$ & $\begin{array}{l}\text { протеин / } \\
\text { protein }\end{array}$ & жир/ fat & $\begin{array}{c}\text { клетчатка/ } \\
\text { cellulose }\end{array}$ & $\Sigma$ \\
\hline 1 & 1,25 & 7,12 & 42,94 & 4,54 & 8,04 & 55,52 \\
\hline 2 & 2 & 7,71 & 42,78 & 5,07 & 5,74 & 53,59 \\
\hline 3 & 3 & 9,59 & 43,63 & 4,24 & 5,62 & 53,49 \\
\hline 4 & 4 & 7,83 & 41,98 & 4,62 & 6,91 & 53,51 \\
\hline 5 & $\begin{array}{l}\text { Термический способ/ } \\
\text { Thermal method }\end{array}$ & 13,73 & 40,35 & 6,92 & 2,58 & 49,85 \\
\hline
\end{tabular}

\section{Обсуждение полученных результатов.}

Определена кривая титрования травяного клеточного сока. В щелочной и кислой средах она имеет перегибы в точках $\mathrm{pH} \sim 7,4$ и $\mathrm{pH} 4,4$.

Из кислых растворов травяного клеточного сока выделены образцы протеиновой пасты, последующим высушиванием определены количества воздушно-сухих проб протеинового концентрата. Необходимо отметить, что сопоставлением приведённых в таблице 1 абсолютных значений масс высушенных проб протеиновой пасты - протеиновых концентратов - не предоставляется возможным однозначно сделать вывод о полноте выделения белковой фракции из растворов в зави- 
симости от величины рН раствора, т. к. при промывании осадков дистиллированной водой возможны потери. Причём в растворах с более низкими значениями рН их могло быть больше, поскольку число промываний было выше.

Образцы протеинового концентрата, полученные ранее с использованием способа высаливания (Шуваев А.В., 2019), также, как и в этой работе, анализировали на процентное содержание атомов углерода, водорода и азота. Сопоставление результатов измерения этих двух работ показывает на более высокое содержание в последних, в среднем по углероду - на 5 \%, водороду - на 0,1 \%, азоту - на 0,6 \%, что является дополнительным подтверждением наличия ионов металлов в образцах протеинового концентрата, выделенных из растворов клеточного сока высаливанием. Из сравнения результатов анализа на процентное содержание атомов в разных пробах (табл. 2) видно, что в протеиновых концентратах, полученных из растворов с различным значением рН, содержание по трём атомам имеет тенденцию к небольшому увеличению при уменьшении значения рН. При сравнении с результатами анализа образца, полученного термическим способом, можно видеть, что в последнем процентное содержание по водороду оказалось выше, по двум другим атомам затруднительно сделать какие-либо выводы. Все эти изменения, по-видимому, каким-то образом связаны с составом полученных при различных условиях протеиновых концентратов. В этом плане результаты измерений процентного содержания атомов не позволяют сделать каких-либо однозначных выводов. По этой причине были продолжены исследования образцов протеинового концентрата с целью выяснения их процентного содержания компонентного состава.

Согласно данным работы Терпиловского К.Ф. и Примакова Н.С. (1975), различие в процентном содержании протеина, полученного термическим способом, по сравнению с аналогичным продуктом, выделенным из растворов травяного клеточного сока другими способами при комнатной температуре (без влияния температуры), может достигать 3 \%, что соответствует результатам нашей работы (табл. 3). Кроме того, для протеинового концентрата, полученного в данной работе термическим способом, процентное компонентное содержание находится в пределах допустимых значений: по протеину $-40 \ldots 61$ \%, жиру $-4 \ldots 14$ \% и клетчатке $-0,5 \ldots .5$ \% (Новиков Ю.Ф. и др., 1985). На основе данных таблицы 3 следует отметить, что в составе образцов, выделенных из растворов под влиянием $\mathrm{HCl}$, не прослеживается какой-либо закономерности в изменении содержания по каждому из четырёх компонентов в зависимости от значений рН исходных растворов травяного сока. Вместе с тем, при сопоставлении результатов анализа по каждому из компонентов отчётливо видно, что в образцах, полученных термическим способом, процентное содержание влаги и жира оказалось выше, а протеина и клетчатки - ниже, чем в образцах, выделенных из растворов с добавлением $\mathrm{HCl}$.

Суммируя результаты анализа по трём важным питательным компонентам (протеин, жир, клетчатка), мы получили примерно одинаковые значения для проб 1-4 (последний столбец табл. 3). Это позволяет сделать предположение, что небольшой разброс в данных обусловлен случайными ошибками измерений. Производя усреднение, получаем значение $54 \pm 1,6$, что выше соответствующей величины 49,85 для результата пробы № 5. В то же время, суммируя результаты анализа по всем четырём компонентам, получаем для проб 1-4 значение 62,1 2,0 , что в пределах погрешности совпадает со значением 63,58 для пробы под № 5 .

Наблюдаемые в таблице 2 закономерности в изменении процентного содержания атомов могут быть связаны с изменением внутреннего аминокислотного состава протеиновой компоненты. Учитывая, что белковая фракция протеинового концентрата имеет сложный состав и состоит из смеси индивидуальных белков, на растворимость и коагуляцию которых большое влияние оказывает рН среды (Хисматуллина 3.Н., 2013). Кроме того, возможно влияние других, не анализировавшихся нами компонентов, например, микроэлементы, витамины, углеводы (Петенко А.И. и Кощаев А.И., 2005). 


\section{Выводы.}

Полученные образцы протеинового концентрата из растворов клеточного сока путём изменения кислотности среды по своим характеристикам вполне пригодны для его использования в качестве кормовых добавок для сельскохозяйственных животных. Описанная в данной работе методика может быть использована на практике для получения протеинового концентрата из раствора клеточного травяного сока.

\section{Литература}

1. Анискин В.И., Негримовский М.Г. Энергосберегающая технология производства гранулированного белково-витаминного корма // Техника в сельском хозяйстве. 2005. № 1. С. 33-37. [Aniskin VI, Negrimovskij MG. Energosberegayushchaya tekhnologiya proizvodstva granulirovannogo belkovo-vitaminnogo korma. Tekhnika v sel'skom khozyaistve. 2005;1:33-37. (In Russ)].

2. Бейтс Р. Определение рН. Теория и практика. 2-е изд., исправ. Л.: Химия, 1972. 400 с. [Beits R. Opredelenie pH. Teoriya i praktika. 2-e izd., isprav. Leningrad: Himiya; 1972:400 p. (In Russ)].

3. Вегетативная масса растений как нетрадиционный источник протеина / А.А. Шевцов, А.В. Дранников, А.А. Дерканосова, А.А. Коротаева // Актуальная биотехнология. 2013. № 1(4). C. 38-40. [Shevtsov AA, Drannikov AV, Derkanosova AA, Korotaeva AA. Vegetative mass of plants, as untraditional source of protein. Aktual'naya biotekhnologiya. 2013;1(4):38-40. (In Russ)].

4. Временный максимально-допустимый уровень (МДУ) содержания некоторых химических элементов и госсипола в кормах для сельскохозяйственных животных и кормовых добавках / Утв. ГУВ Госагропрома СССР 07.08.1987 г. № 123-4/281-87. М.: Агропромиздат, 1989. С. 1-2. [Vremennyi maksimal'no-dopustimyi uroven' nekotorykh khimicheskikh elementov i gossipola v kormakh dlya sel'skokhozyaistvennykh zhivotnykh. Utv. GUV Gosagroproma SSSR 07.08.1987 g. № 123-4/28187. Moscow: Agropromizdat; 1989:1-2. (In Russ)].

5. Гаврилов Д.А., Шуваев А.В. Влияние электролитов на процесс выделения белковой фракции из растворов травяного клеточного сока // Химия и жизнь: сб. ст. ХІХ междунар. науч.практ. конф., (г. Новосибирск, 14 мая 2020 г.). Новосибирск: ИЦ НГАУ «Золотой колос», 2020. C. 95-99. [Gavrilov DA, Shuvaev AV. Vliyanie elektrolitov na process vydeleniya belkovoj frakcii iz rastvorov travyanogo kletochnogo soka. (Conference proceedigs) Himiya i zhizn': sb. statej XIX mezhdunar. nauch.-prakt. konf. (g. Novosibirsk, 14 maya 2020 g.). Novosibirsk: ITs NGAU «Zolotoi kolos»; 2020:95-99. (In Russ)].

6. Киреева В.В. Технология комплексной переработки растительного сырья с получением пищевых белковых добавок // Известия высших учебных заведений. Пищевая технология. 2004. № 5-6. C. 50-52. [Kireeva VV. Tekhnologiya kompleksnoi pererabotki rastitel'nogo syr'ya s polucheniem pishchevykh belkovykh dobavok. Izvestiya vysshikh uchebnykh zavedenii. Pishchevaya tekhnologiya. 2004;5-6:50-52. (In Russ)].

7. Конвейерная гелиосушка с перекрёстным током теплоносителя / Е.С. Умбетов, Л.А. Уткин, Р.А. Омаров, Ы.Д. Осмонов // Международный журнал прикладных и фундаментальных исследований. 2016. № 1-1. С. 19-22. [Umbetov ES, Utkin LA, Omarov RA, Osmonov ID. The conveyor heliodryer with cross current of the heat carrier. International Journal of Applied and Fundamental Research. 2016;1-1:19-22. (In Russ)].

8. Кудряшова Н.С., Бондарева Л.Г. Физическая и коллоидная химия: учебник и практикум для СПО. 2-е изд., перераб. и доп. М.: Изд-во Юрайт, 2018. 379 с. [Kudryashova NS. Bondareva LG. Fizicheskaya i kolloidnaya khimiya: uchebnik i praktikum dlya SPO. 2-e izd., pererab. i dop. Moscow: Izd-vo Yurait; 2018:379 p. (In Russ)].

9. Нормы и рационы кормления сельскохозяйственных животных: справ. пособие / А.П. Калашников и др. 3-е изд., перераб. и доп. М.: Агропромиздат, 2003. 456 с. [Kalashnikov AP et al. Normy i ratsiony kormleniya sel'skokhozyaistvennykh zhivotnykh: sprav. posobie. 3-e izd., pererab. i dop. Moscow: Agropromizdat; 2003:456 p. (In Russ)]. 
10. Петенко А.И., Кощаев А.И. Концентрат из сока люцерны // Птицеводство. 2005. № 5. C. 28-29. [Petenko AI, Koshchaev AI. Kontsentrat iz soka lyutserny. Ptitsevodstvo. 2005;5:28-29. (In Russ)].

11. Полунин А.А., Абдулкеримов С.А. Экономические аспекты оценки эффективности энергопотребления в сельском хозяйстве // Экономика сельского хозяйства России. 2014. № 7. C. 46-52. [Polunin A, Abdulkerimov S. Economic aspects of an assessment of efficiency of consumption of energy in agriculture. Economics of Agriculture of Russia. 2014;7:46-52. (In Russ)].

12. Попов В.В. ИВК: лучше меньше, но лучше // Аграрное обозрение. 2014. № 6(46). С. 6062. [Popov VV. IVK: luchshe men'she, no luchshe. Agrarnoe obozrenie. 2014;6(46):60-62. (In Russ)].

13. Прищеп Л.Г., Бойко А.Я. Динамика энергозатрат на консервирование кормов // Механизация и электрификация социалистического сельского хозяйства. 1974. № 7. С. 7-8. [Prishchep LG, Bojko AYA. Dinamika energozatrat na konservirovanie kormov. Mekhanizaciya i elektrifikaciya socialisticheskogo sel'skogo hozyajstva. 1974;7:7-8. (In Russ)].

14. Ревякин Е.Л. Эффективность ресурсосберегающих технологий в растениеводстве // Техника и оборудование для села. 2013. № 9(195). С. 18-22. [Revyakin EL. Efficiency of resourcesaving technologies in crop production. Machinery and Equipment for Rural Area. 2013;9(195):18-22. (In Russ)].

15. Рекомендации по использованию клеточного сока, протеиновой пасты и сухого протеинового концентрата из зелёных растений в кормлении сельскохозяйственных животных / Ю.Ф. Новиков и др. Запорожье, 1985. 27 с. [Novikov YuF et al. Rekomendatsii po ispol'zovaniyu kletochnogosoka, proteinovoi pasty i sukhogo proteinovogo kontsentrata iz zelenykh rastenii v kormlenii sel'skokhozyaistvennykh zhivotnykh. Zaporozh'e; 1985:27 p. (In Russ)].

16. Способ получения кормовой добавки из сока растений: пат. 2233597 Рос. Федерация / А.И. Кощаев, А.И. Петенко, Г.А. Плутахин. Заявл. 15.11.02; опубл. 10.08.04, Бюл. № 22. [Koshchaev AI, Petenko AI, Plutakhin GA. Sposob polucheniya kormovoi dobavki iz soka rastenii: pat. 2233597 Ros. Federatsiya. Zayavl. 15.11.02; opubl. 10.08.04, Byul. № 22. (In Russ)].

17. Терпиловский К.Ф., Примаков Н.С. Влияние температуры сушильного агента на качество белково-витаминного концентрата // Доклады Всесоюзной академии сельскохозяйственных наук им. В.И. Ленина. 1975. № 7. С. 44-45. [Terpilovsky KF, Primakov NS. Vliyanie temperatury sushil'nogo agenta na kachestvo belkovo-vitaminnogo kontsentrata. Doklady Vsesoyuznoi akademii sel'skokhozyaistvennykh nauk im. Lenina VI. 1975;7:44-45. (In Russ)].

18. Хисматуллина 3.Н. Методы фракционирования смеси белков на индивидуальные белки // Вестник Казанского технологического университета. 2013. Т. 16. Вып. 21. С. 212-217. [Khismatullina ZN. Metody fraktsionirovaniya smesi belkov na individual'nye belki. Herald of Kazan Technological University. 2013;16(21):212-217. (In Russ)].

19. Цугленок Н.В., Матюшев В.В., Цугленок Г.И. Повышение энергетической эффективности использования технических средств отжатия зелёного сока растений за счёт конструктивного совершенствования системы питания // Вестник КрасГАУ. 2012. № 5. С. 305-311. [Tsuglenok NV, Matyushev VV, Tsuglenok GI. Power efficiency increase of the technical facilities use for green plant moisture squeezing by means of power supply system constructive perfection. Bulletin of KrasGAU. 2012;5:305-311. (In Russ)].

20. Шуваев А.В. Выделение белковой фракции из растворов кормового клеточного сока путём добавок электролитов [Электронный ресурс] // Наука и образование: новое время. 2018. № 5(28). C. 138-144. [Shuvaev AV. Isolation of the protein fraction from solutions of fodder"s cell juice by adding electrolytes [Elektronnyi resurs]. Science and education: new time. 2018;5(28):138-144. URL: https://articulusinfo.ru/category/06-00-00-selskohozyajstvennye-nauki/?tag=5-sentyabr-oktyabr-2018-g (In Russ)].

21. Шуваев А.В. Выделение протеинового концентрата из растворов травяного клеточного сока // Животноводство и кормопроизводство. 2019. Т. 102. № 3. С. 149-155. [Shuvaev AV. Isolation of a protein concentrate from solutions of herbal cell juice. Animal Husbandry and Fodder Production. 2019;102(3):149-155. (In Russ)]. doi: 10.33284/2658-3135-102-3-149 
22. Яковлев Д.А. Теоретические исследования процесса отжима сока шнековым рабочим органом с дополнительным дренирующим контуром // Вестник Донского государственного технического университета. 2011. Т. 11. № 7(58). С. 997-1004. [Yakovlev DA. Theoretical studies of juicing by screw operating device with extra drainage contour. Vestnik Donskogo gosudarstvennogo tekhnicheskogo universiteta. 2011;11(7-58):997-1004. (In Russ)].

\section{References}

1. Aniskin VI, Negrimovsky MG. Energy-saving technology for the production of granulated protein-vitamin feed. Machinery in Rural Agriculture. 2005;1:33-37.

2. Beits R. Determination of $\mathrm{pH}$. Theory and practice. $2^{\text {nd }}$ ed., Rev. Leningrad: Chemistry; 1972:400 p.

3. Shevtsov AA, Drannikov AV, Derkanosova AA, Korotaeva AA. Vegetative mass of plants, as untraditional source of protein. Actual Biotechnology. 2013;1(4):38-40.

4. Temporary maximum permissible level (MVA) of some chemical elements and gossypol in feed for agricultural animals and feed additives. Ut. GUV of State Agricultural Committee of the USSR 07.08.1987 No. 123-4/281-87. Moscow: Agropromizdat;1989:1-2.

5. Gavrilov DA, Shuvaev AV. The influence of electrolytes on the process of you-dividing the protein fraction from solutions of herbal cell juice. (Conference proceedings) Chemistry and life: sb. Art. XIX international scientific. conf., (Novosibirsk, May 14, 2020). Novosibirsk: IC NGAU "Golden Spike"; 2020:95-99.

6. Kireeva VV. Technology of complex processing of plant raw materials with obtaining food protein additives. News of Higher Educational Institutions. Food technology. 2004;5-6:50-52.

7. Umbetov ES, Utkin LA, Omarov RA, Osmonov ID. The conveyor heliodryer with cross current of the heat carrier. International Journal of Applied and Fundamental Research. 2016;1-1:19-22.

8. Kudryashova NS, Bondareva LG. Physical and colloidal chemistry: textbook and workshop for the ACT. 2-e nd ed., Redesign. and supplement. Moscow: Publishing House Urright; 2018:379 p.

9. Kalashnikov AP et al. Standards and diets of farm animals: Ref. book. 3rd ed., rework. and add. Moscow: Agropromizdat; 2003:456 p.

10. Petenko AI, Koshchaev AI. Alfalfa juice concentrate. Poulty Farming. 2005;5:28-29.

11. Polunin A, Abdulkerimov S. Economic aspects of an assessment of efficiency of consumption of energy in agriculture. Economics of Agriculture of Russia. 2014;7:46-52.

12. Popov VV. IVK: it is better less, but better. Agricultural review. 2014;6(46):60-62.

13. Prishchep LG, Boyko AYa. The dynamics of energy consumption for the preservation of feed. Mechanization and Electrification of Socialist Rural Agriculture. 1974;7:7-8.

14. Revyakin EL. Efficiency of resource-saving technologies in crop production. Machinery and Equipment for Rural Area. 2013;9(195):18-22.

15. Novikov YuF et al. Recommendations for the use of cell juice, protein paste and dry protein concentrate from green plants in feeding farm animals. Zaporozhye; 1985:27 p.

16. Koshchaev AI, Petenko AI, Plutakhin GA. A method of obtaining a feed additive from plant juice: US pat. 2233597 Ros. Federation. Declared 15.11.02; Publ. 10.08.04, Bull. Number 22.

17. Terpilovsky KF, Primakov NS. The effect of the temperature of the drying agent on the quality of protein-vitamin concentrate. Reports of the All-Union Academy of Agricultural Sciences named after Lenin VI. 1975;7;44-45.

18. Khismatullina ZN. Methods of fractionating a mixture of proteins into individual proteins. Herald of Kazan Technological University. 2013;16(21):212-217.

19. Tsuglenok NV, Matyushev VV, Tsuglenok GI. Power efficiency increase of the technical facilities use for green plant moisture squeezing by means of power supply system constructive perfection. Bulletin of KrasGAU. 2012;5:305-311. 
20. Shuvaev AV. Isolation of the protein fraction from solutions of fodder's cell juice by adding electrolytes. Science and education: new time. [Internet]. 2018;5(28):138-144. Available from: https://articulus-info.ru/category/06-00-00-selskohozyajstvennye-nauki/?tag=5-sentyabr-oktyabr-2018-g.

21. Shuvaev AV. Isolation of a protein concentrate from solutions of herbal cell juice. Animal Husbandry and Fodder Production. 2019;102(3):149-155. doi: 10.33284/2658-3135-102-3-149

22. Yakovlev DA. Theoretical studies of juicing by screw operating device with extra drainage contour. Vestnik of Don State Technical University. 2011;11(7-58):997-1004.

Шуваев Александр Васильевич, кандидат химических наук, доцент кафедры «Гидравлика, водоснабжение и химия», Сибирский государственный университет путей сообщения, 630049, г. Новосибирск, ул. Дуси Ковальчук, д. 191, тел. 8-953-867-00-20, e-mail: shuvaev53@mail.ru

Поступила в редакцию 17 августа 2021 г.; принята после решения редколлегии 13 сентября 2021 г.; опубликована 30 сентября 2021 г. / Received: 17 August 2021; Accepted: 13 September 2021;

Published: 30 September 2021 